\title{
建物群內外における流れ場の乱流特性と組織運動
}

Turbulence Characteristics and Organized Motions in and above Building Clusters

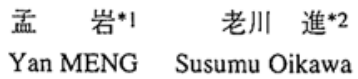

This review considers observational and experimental knowledge of turbulence characteristics and organized motions in and above building clusters, drawing from both atmospheric and laboratory data. The former describe the structure of the roughness sublayer in which the roughness has a direct dynamical influence, whereas the latter resolve the flow structure within building clusters in some detail. Topics considered include the turbulent velocity fields and organized motions above the cluster layer, properties of the wake flow within building clusters, and the nature of the separation bubble on the building roof. Overall, there are three types of turbulent flows which play important roles in the transport of heat and pollutants in and above building clusters: the organized motions transport heat near the cluster layer and decrease unstable conditions in the urban area, the turbulent wake flows determine the maximum values of concentration at ground-level, and the separations on the building roof control transport and dispersion of tracer gas emitted from the rooftop.

Key Words : Roughness sublayer, Building clusters, Turbulence characteristic, Organized motion,

Flow pattern, Separation bubble.

1.はじめに

近年、コージェネレーションシステム（熱電併給システ

ム）の急速な普及に伴い、建物近傍の大気污染問題が奬念 されている。コージェネシステムは、高いエネルギー効率 を有する反面、燃焼過程で生成される高レベルの窒素酸化 物(NOx)を建物近傍に排出する。高い煙突から排出される 大気污染物質の拡散問題と巽なり、低い煙突から排出され る大気污染物啠の拡散現象は建物群内外における流れ場の 乱流特性とそこに存在するいろいろなタイプの乱流組織運 動に強く依存する。

一般に都市域の大気境界層はFig.1に示すような 3 つ層 に分けることができる。上層のエクマン層はコリオリスカ の影剅を受け、風向は上層に行くにつれ時計方向に回転 し、風速分布は速度欠損法則に従う。一方、中間の慣性層 (あるいは接地層と呼ぶ) は地表面の粗度及び大気安定度 の影響を受け、風向はほほ一定であり、風速分布は普遍化 対数則により表される。高い煙突から排出される大気污染 物質はこの二つの層の重なり合うところで拡散し、その濃 度分布は正規型の拡散モデルにより容易に予測される。し かし、低い煙突からの大気污染物は最下層のラフネスサブ レイアに排出されるため、その潡度分布の予測は困難が伴 う。その理由としては、ラフネスサブレイア内の流れは建 物の存在により、高さ方向にも水平方向にも複雑な構造を もっていることが挙げられる。更に建物屋上に排出源があ る場合には污染物質の拡散ブロセスが建物近傍の剥離性状 に大きく依存することとなる。ラフネスサプレイア内の大 気拡散現象の解明には、建物群内外における複雑な乱流運 動を明らかにする必要がある。

本報告では、著者らゆ〜7)の近年建物群内外における流れ

*1 清水建設(株)技術研究所 研究貝 工博 Research Engineer, DR. ENG, SHIMIZU Corp.
と拡散に関して行った現地観測及び風洞実験の結果につい て紹介する。建物群内外における流れ場の乱流特性および そこに存在するいろいろなタイプの乱流組織運動を示すと 共に、建物屋上に排出される污染物質の拡散プロセス と建物近傍の複雑乱流場との関係を明らかにする。

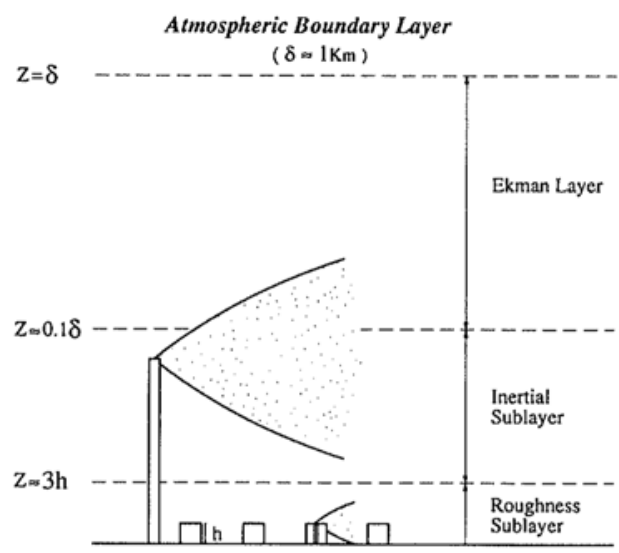

Fig. 1 都市域における大気境界層の構造

\section{2. 観測及び風洞実呀の結果}

建物群内外における流れ場の乱流特性及びそこに存在す る乱流組織運動を明らかにするために、本研究では以下に

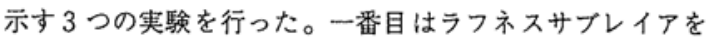
着目した現地観測を行い、建物群上層の流れ場の乱流構造 を調べる11.2)。二番目は風洞実験により建物群内の流れ場を 測定し、建物密度が流れと拡散のパターンに及ほす影響を 明らかにする3).4)。三番目は建物の屋上の流れ場を調べ、流

*2 清水建設(株)技術研究所 主任研究員 工博 Chief Research Engineer, DR. ENG, SHIMIZU Corp. 
れの剥離に伴う乱流場の詳細構造とそのスペクトル特性を 解明すると共に、流れの剥離と污染物質の拡散プロセスと の関係を明らかにする5) 7)。

\section{1 建物群上層の流れ場の乱流棈造}

都市域における乱流観測は古くから行われている。しか し、既往の研究のほとんどは、建物群のかなり上あるいは その内に限られたもので、建物群内外にわたる広い籁囲で の乱流特性及び組織運動については不明点が多い。本研究 は、建物群内外の流れ場の垂直乱流構造および組織的乱流 運動を明らかにすることを目的とし、3台の超音波風速計 を建物群内およびその上層の異なる高さに設置し都市郊外 の住宅地で野外観測を行った。観測は、札幌市の中心より 北西10kmにある住宅地にて行つた。観測点の北西側 $30 \mathrm{~m} の$ 所から平均建物高さ $7 \mathrm{~m}$ 、建蔽率約 $25 \%$ の均一な住宅が続い ている。観測点の南側は、北海道工業大学のサッカーグラ ンドであり、北東から南東方向に $200 \mathrm{~m}$ までは開けた平坦 地である。観測点は住宅地から30m離れた所に設置され た。本研究で報告するデータは2つの期間（Period A：1991 年の7月;Period B：1992年の11月）に钼測したものである。 Fig. 2に観剆機器の設置状況を示す。

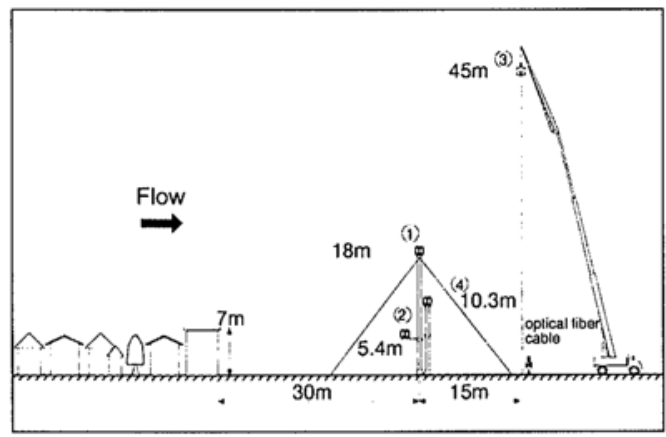

Fig. 2 野外钼測機器の設置状況

まず、建物群上層の流れ場の乱流統計的性質を述べる。 Fig. 3に各速度成分の標準偏差とレイノルズ応力の鉛直分 布を示す。縦軸は無次元化した高さ $/ \mathrm{h}(\mathrm{h}:$ 建物群平均高さ $7 \mathrm{~m})$ で表示した。○印(Period A)および口印(Period B )は9Run の平均值を示し、エラーバーは標準誤差を表す。Fig.3(a) (c)には、変動風速の標準偏差を高さ $18 \mathrm{~m}$ の摩擦速度 $u_{*_{r}}$ で基 準化した垂直分布を示す。 $\sigma_{\mathrm{u}}$ の垂直分布は建物群上にブ ロードなピークを示し、更にその上層で $\sigma_{\mathrm{u}}$ の值は高さとと もに減少する。一方、 $\sigma_{\mathrm{v}} お よ ひ ゙ \sigma_{\mathrm{w}}$ の垂直分布は概ね一定の 値を示す。Period AおよびPeriod Bの両期間における $\sigma_{w} / u_{*}$ の値はよい一致を示すが、 $\sigma_{\mathrm{u}} / \mathrm{u}_{*_{\mathrm{r}}}$ および $\sigma_{\mathrm{v}} / \mathrm{u}_{*_{\mathrm{r}}}$ の両期間の 值は少し異なっている。Fig.3(d)には、無次元化したレイ ノルズ応力の垂直分布を示す。レイノルズ応力の垂直分布 は、建物群上部1.5h付近に弱いピークを持ち、更にその上 でレイノルズ応力の值は高さとともに減少する。

建物群上層部におけるレイノルズ応力のピークの形成メ カニズムを探るため、各象限におけるレイノルズ応力 -<u'w'> $>_{\mathrm{i}} / \mathrm{u}_{\mathrm{r}} 2$ 2の垂直分布をFig.4に示す。乱流エネルギー生 成に正の寄与をする第2象限(ejection)および第4象限(sweep)の 値が、第 1 象限(outward interaction)および第3象限(inward interaction)の值に比べ、かなり大きくかつ建物群の上部にピーク 値を持つ。一方、outwardおよびinward interactionは建物群内 外において、ほほ一様に分布している。このことから、 Fig.3に示された建物群上部におけるレイノルズ応力のピー クの形成が組織運動によるものと説明される。また、 ejectionおよびsweep運動の寄与率が 3h上方で急速に減少 していることから、建物群上層の組織運動の上限、すなわ ち、ラフネスサブレイアの上限が3hに存在すると推定され る。
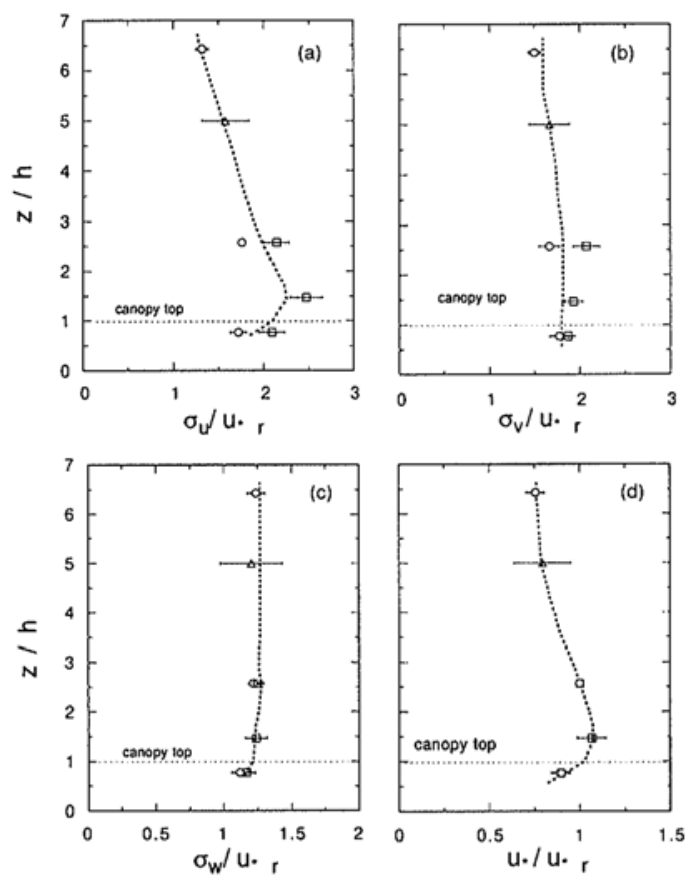

Fig. 3 基準化した (a) $\sigma_{u}$, (b) $\sigma_{v}$,(c) $\sigma_{\mathrm{w}}$, (d) u*の垂直分 布

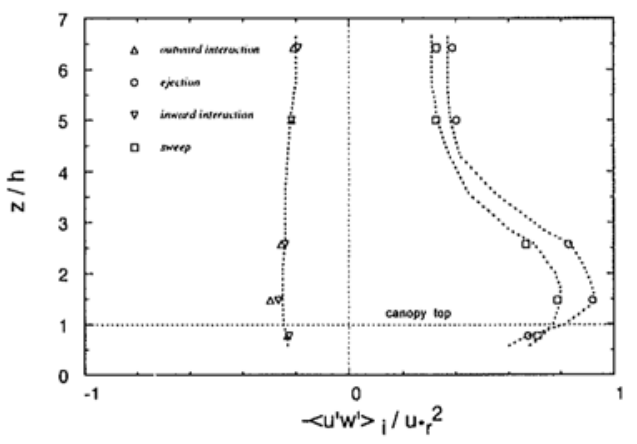

Fig.4 各象限における基準化したレイノルズ応力の分布 建物群上部における組織運動の全体像を把握するため に、速度変動と温度変動の時系列の変化及びその条件付き 平均の結果を示す。Fig. $5 に$ は、高度 $18 \mathrm{~m}$ および $5.4 \mathrm{~m}$ の速度 変動、温度変動および瞬時レイノルズ応力の時系列プロッ トを示す。ここで特徴的なことは、正の瞬時レイノルズ応 
力 $\left(-\mathrm{u}^{\prime} \mathrm{w}^{\prime}>0\right)$ が、ほほ同時刻にキャノピー上層 $18 \mathrm{~m}$ とキャ ノピー内5.4mにおいて出現している。 sweep時 $\left(\mathrm{u}^{\prime}>0, w^{\prime}<0\right)$ においては、上方からの高速流が地表方向に移動し、この 流れに伴い、冷たい空気はキャノピーの上方から下方に翰 送され負の温度変動を生じさせる。一方、 ejection時( $\mathrm{u}^{\prime}$ $<0$, w'>0)には、低速流が下方から上方に運ばれ、この流れ に伴い、暖かい空気が持ち上げられ正の温度変動を起こ す。 sweepとejection運動に伴う温度変動は高度 $5.4 \mathrm{~m}$ と $18 \mathrm{~m}$ においてほほ同時に生じており、その周期は約100秒であ る。また温度変動はゆるやかな上䒜の後に急激に降下する ことから、温度のramp現象と呼ばれている。本研究は、相 対的に大きなramp現象を抽出するために、アンサンブル平 均法を用いて解析を行った。Fig. 6には、高さ $5.4 \mathrm{~m} 、 10.3 \mathrm{~m}$

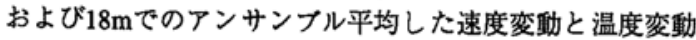
をxz断面に示すものである。点線および実線は、各々温度 変動が平均値以下の值と平均值以上の値を 0.05 ○刻みで表 示したものである。温度変動のゼロ値を示す楾が上昇流お よび下降流の領域を分離し、各々の領域に正および負の温 度変動が生じている。その結果、正の熱フラックスが作ら れ、キャノピー内外の温度場が均一化されることになる。
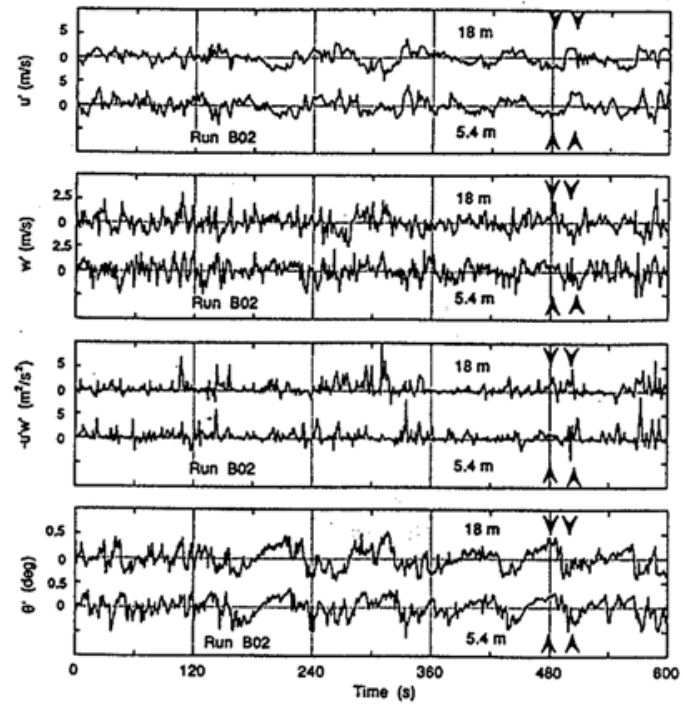

Fig. 5 高度 $18 \mathrm{~m}$ および $5.4 \mathrm{~m}$ の速度変動、瞬時レイノルズ 応力および温度変動の時系列変化

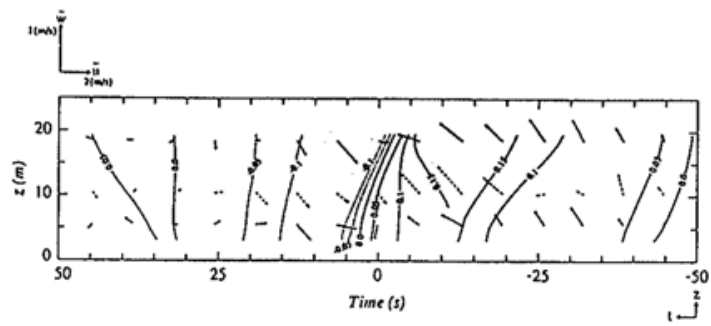

Fig. $6 \mathrm{xz}$ 断面におけるアンサンブル平均した速度変動の ベクトルと温度変動のコンター

このように、正の温度変動は ejection運動によって起こさ れ、負の温度変動はs weepによって起こされていることか ら考えると、ここで得られた組織運動は、建物群内外で熱
堭の輸送に重要な役割を担っていることが明らかである。 ラフネスサブレイア内において、日中強い温度勾配が破壊 されるメカニズムは組織運動による機械的な混合そのもの である。Fig. 7にはラフネスサブレイアにおける組織運動の 概念図である。

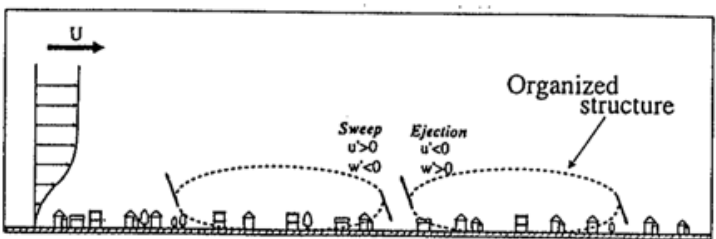

Fig.7 ラフネスサブレイア内における組織運動の概念図

\section{2 建物群内の流れ構造}

建物群内の流れ場は建物群上層のそれより複雑である。 特に建物密度が高い場合、建物群内の流れ場のパターンが 建物密度によって变化し、その影隦で建物近傍の拡散パ ターンも変化する。その結果、単体建物の場合に比へ、建 物群内の地表面湄度は 1 析大きくなることもある。この様 な現象については建物密度が建物群内の流れ場と濃度場に 与える影響を系統的に調べる必要がある。実際の都市の形 態は、建物が整然と並んでいる場合もあれば、不規則に並 んでいる場合もある。その時の流れ場は、前後の建物の干 涉により影響を受ける以外に、近隣の建物間の相互作用に よる影響も受ける。こうした流れ場については、これまで 定量的に調べた例はない。本研究では、風洞において立方 体のモデル建物を千鳥状に配列し、建物密度を系統的に変 化させた時の流れ場と拡散場を定量的に調べた。

実験は清水建設(株)技術研究所の小型回流式風洞を用いて 行った。風洞の測定部の長さは $7 \mathrm{~m}$ 、測定断面の高さと幅は それぞれ0.9mと1.1mである。Fig.8には本風洞実験の概要を 示した。高さ $8 \mathrm{~cm}$ の木製の立方体モデル建物を測定部入り口 より主流方向に千鳥状に配置し、その密度を10\%から40\%ま で変化させた。Fig.9は建物の配置状況を示す。

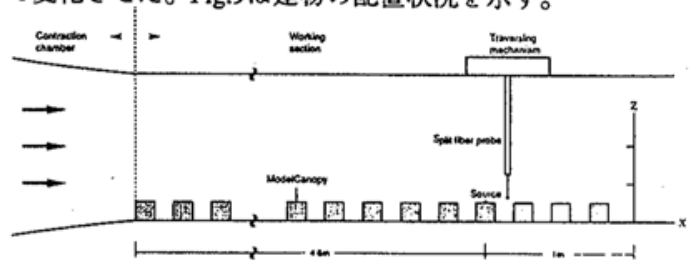

Fig.8 風洞実験の概要

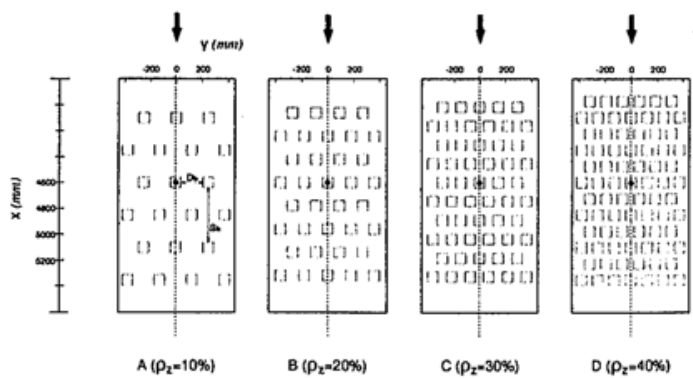

Fig.9 建物の配置状況 
(a)

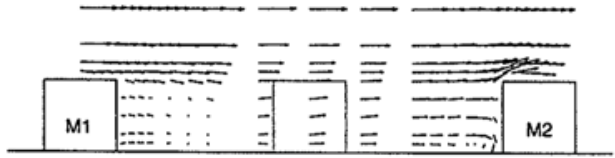

(b)

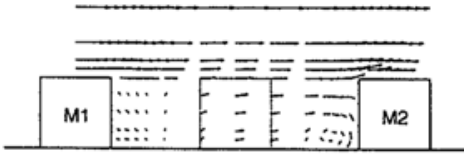

(c)

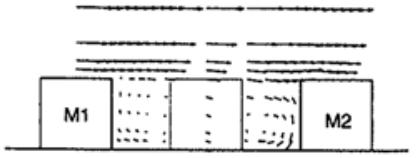

(d)

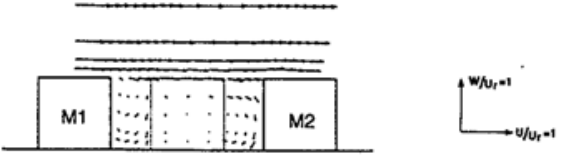

Fig.10y/H=0の鉛直断面内における平均速度のベクトル図 (a) 密度10\% ; (a) $20 \%$; (a) $30 \%$; (a) $40 \%$

(a) (b)
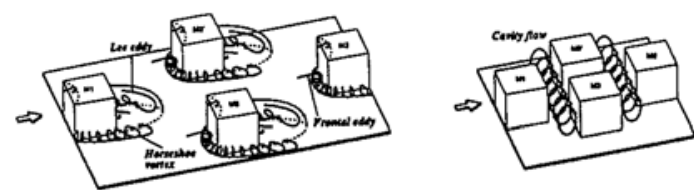

Fig.11 流れパターンの模式図

Fig.10(a)〜 (d)には建物密度を10\%から40\%まで変化させ た時の平均速度のベクトル図 ( $\mathrm{y} / \mathrm{H}-0$ の鉛直断面内) を示 す。各速度成分は、基劷風速U,で無次元した。基梁風速U, は建物の影響を受けていない高さ $5 \mathrm{H}(\mathrm{z}-40 \mathrm{~cm})$ の風速值 を用いた。建物密度10\%の埸合（Fig.10(a)）、建物M1の後 流城に影著な lee eddyが生し、その下に弱い下降流に伴う

2 次流(secondary flow) が存在する。後流の再付着は、建物 背面から䄪1H離れたところに見られる。再付着点を離れる と、建物下層での風速が回復し始め、速度ベクトルも上向 きに転じる。一方、建物M2風上面の前方では、建物高さ 2/3以下の領域にfrontal eddyと呼ばれる小さな渦が見られ、

また、建物 $\mathrm{M} 2$ 前緣の角部に強い上昇流が存在する。建物 密度10\%時の流れのパターンは、全体的に見ると、単体建 物の場合のそれによく似ている。建物密度が20\%になると

(Fig.10(b)）、流れのパターンはすこし変化する。建物M1 の後流域のlee eddyが小さくなる一方、建物M2風上面の前 方のfrontal eddyがかなり大きくなる。また、建物M2前縁の 角部の上昇流は、10\%の場合に比べかなり弱くなってい る。建物密度が30\%以上になると（Fig.10(c)、(d)）、流れ のパターンは単体建物の場合と全く異なっている。まず、 建物M2の前緣の角部には上昇流が全く見られず、風があ たかも建物の屋根面を滑るように流れている。一方、建物 $\mathrm{M} 1$ と建物M2の間に、二つの大きな循舆流が形成されてい
る。この二つの循環流の大きさは、それぞれ建物M1と斜め 後の建物M3 (Fig.11を参照) の間の距離、または建物M2と 斜め前の建物M3との間の距離にほほ等しい。建物M2の前方 に存在する循環流は、建物M2の前面に強い下降流を引き起 こしている。以上の結果から、建物が千鳥状に配列した場 合の流れ場の特徵をFig.11に示すような模式図で表すことが できる。建物密度が10\%以下の場合 (Fig.11(a)) は、建物群 落内の個々の建物周辺の流れ場が単体建物周辺の流れ場と ほほ同様であり、"isolated roughness flow"と呼ぶことが できる。一方、建物密度が30\%を越えると（Fig.11(b)）、安 定した循環流 (cavity flow) が建物間に形成される。この場 合、建物群落の上空の流れも、建物間に入りにくくなり、" skimming flow "と呼ばれるような流れとなる。isolated roughness flowから skimming flowへの邊移状態である建物密 度 $20 \%$ の場合、上流側の建物M1背後のlee eddy と斜め後方の 建物M3前方のfrontal eddyと、あるいは下流㑡の建物M2前面 のfrontal eddyと斜め前の建物M3背後のlee eddyと相互干涉し 始まる。その結果、建物背後のlee eddyが小さくなる一方、 建物M2前面のfrontal eddyがかなり大きくなる。また建物側 面近くに馬蹄形渦が見られなくなる。上流㑡の建物の後流 が斜め後方の建物前方の流れ場を干涉することで、"wake interference flow"と呼ぶことができる。

建物群内の流れパターン変化は、そこに排出されたト レーサガスの拡散バターンにも大きな影箱を与える。Fig.12 には、建物密度が10\%から40\%までに変化させた場合にy /H-0の鉛直断面における淟度分布のコンターを示す。建物 背後の高港度城は建物密度によらず高さ $\mathrm{z}-\mathrm{H}$ 近傍に形成され るが、地表面での最大漕度は建物密度が高くなるにつれ大 きくなる。これは建物屋上から排出されたガスが風下にあ る建物の前面に存在する cavity flowにより地表面へ向かって 輸送されたことによるものである。

(a)

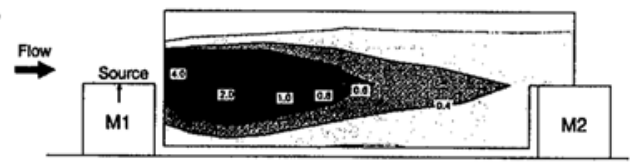

(b)

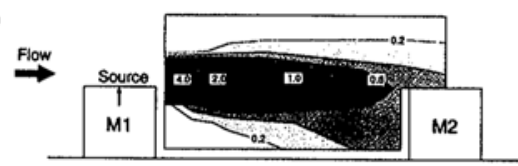

(c)

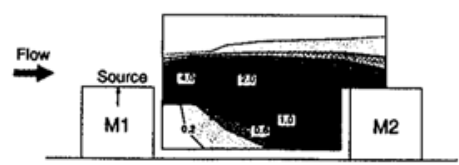

(d)

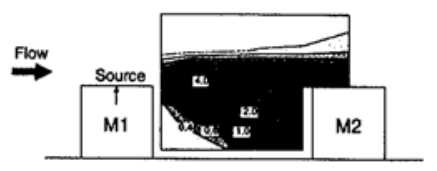

Fig.12 y/H-0の鉛直断面内における蕞度コンター (a) 密度10\%；(a) $20 \%$; (a) $30 \%$; (a) $40 \%$ 


\section{3 剥離に伴う流れ堨の乱流構造}

建物屋上に排出源がある場合には污染物 質の拡散プロセ スが建物近傍の剥離性状に大きく依存する。平均淟度分布 を予測する場合には、建物屋上における風速の平均値とそ の標舫偏差が必要となるが、瞬間濃度を予測する場合に は、更に建物屋上の風速のパワースペクトルが必要とな る。しかし、建物屋上の各速度成分のパワースペクトル特 性を報告した研究例は殆どない。本研究では、自然風を模 擬した乱流境界層に置かれたモデル建物の屋上の各速度成 分の平均值、標準偏差及びパワースペクトルを調へるとと もに、流れの剥離と污染物質の拡散プロセスとの関係を明 らかにする。

Fig.13は風向角0度の屋根面上の平均的な流れパターンを 概念的に示したものである。ここで対称軸線上に 3 つの測 定点を設け、流れ場の乱流特性を詳細に調べた。Fig.14に は風向 0 度における平均速度U、V、wの鉛直分布を示す。 平均速度の値は軒高風速により基陆化されている。屋根面 前緣 $\mathrm{A}$ 点での平均速度Uの鉛直分布が接近流のそれとほほ 一致しているのに対して、平均速度Wは屋根面近傍におい て大きく增大している。平均速度Wの最大値は風洞風速の 7割にも達し、吹上角度に換算すると39度となっている。 一方、屋根面の中央と風下側の測定点BとCでは平均速度U が屋根面近傍において接近流の值よりかなり小さくなる が、屋根面から離れると反対に大きくなる。平均速度の屋 根面上の增大は流れが建物屋面前縁で剥離することにより 気流が屋根面の上空に排除されることによるものである。 この剥離流の影慗で平均速度Wの值は測定点B、Cにおいて 若千負の值となっている。Fig.15には風向0度における変動 速度の標华偏差 $\sigma_{v} 、 \sigma_{v} 、 \sigma_{w}$ の鉛直分布を示す。変動速度の 標染偏差の值は軒高での接近流の各速度成分の標劷偏差に より基染化されている。屋根面前縁A点における変動速度 の標华偏差考の分布は接近流のそれによく一致している が、 $\sigma_{v} 、 \sigma_{\mathrm{v}}$ の鉛直分布は屋根面に近づくにつれ大きくなっ ている。それに対して、屋根面の中央の測定点Bでは $\sigma_{4}$ の、分布に大きなピークが見られる。これらの大きな乱れ は建物屋根面前緣の剥離渦によって作られたもので、剥離 瀜の影豐は屋根面の風下㑡の測定点Cにも見られる。ま

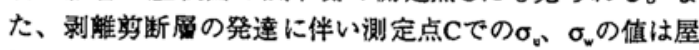
根面から唯れる所において測定点 Bでの值より大きくなっ ている。

Fig. 16(a) 〜 (f)には風向0度の場合の速度成分u、v、wのパ ワースペクトルをに示す。紸軸は軒高での接近流の各速度 の分散により無次元化し、横軸は建物の見付け幅と軒高風

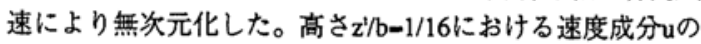
パワースペクトルの值は、風上面上の測定点Aを除いて、 0.2 3までの周波数域において接近流の值の約 10 倍となっ ている。一方、速度成分、のスペクトルの増大は低周波数 域にも見られ、その影㳯は屋根面近傍に大きく、 $\sigma_{v}$ の最大 値が屋根面近傍に形成される原因にもなっている。屋根面 前縁の剥離渦の影響は速度成分wのパワースペクトルに最 も顕著に現れている。屋根面の中央と風下側に位置する測 定点B、Cでの速度成分Wのパワースペクトルに見られた大

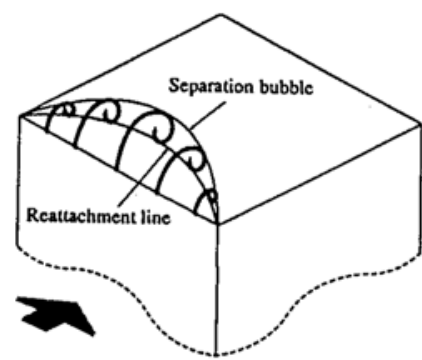

Fig.13 屋根面上の流れパターンの概念図
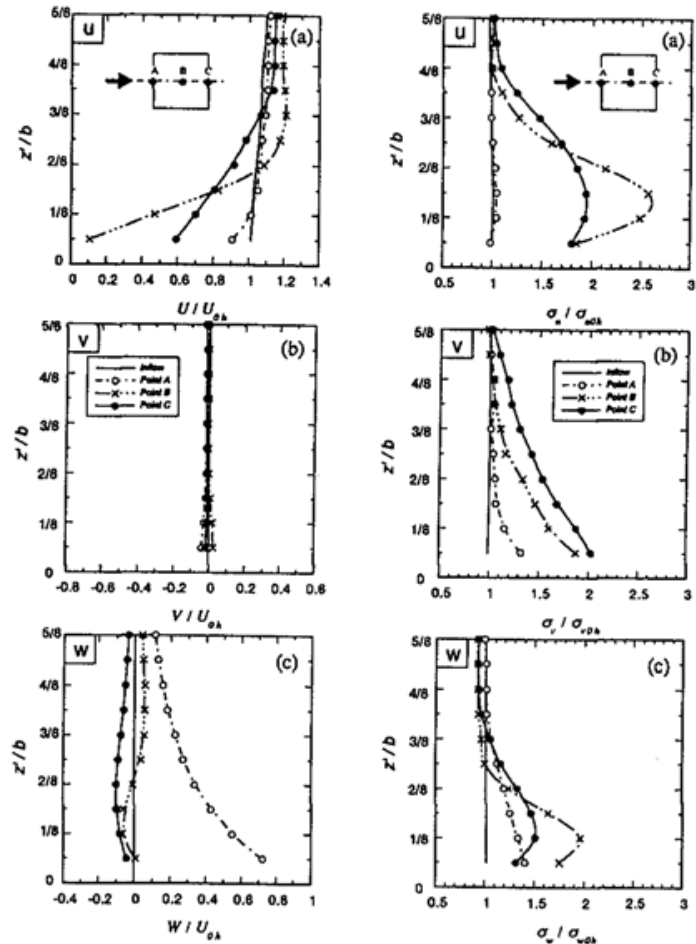

Fig.14 風向0度における平 均速度の鉛直分布

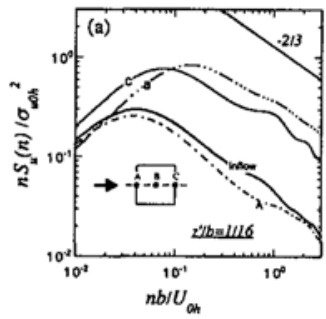

Fig.15 風向0度における変 動速度の鉛直分布

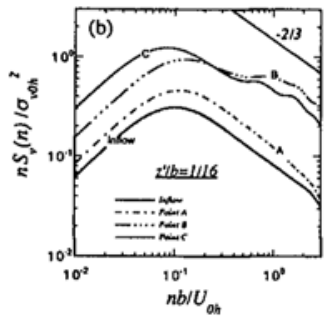

Fig.16 風向0度における建物屋上の変動速度のスペクトル 
きなピークはその結果である。このピークの無次元周波数 は約 1 であり、建物後流渦の無次元周波数より一栴高い。 屋根面前縁剥離渦の移流速度が軒高風速の5 7割であると 考えると、屋根面の剥離渦の規模は建物の見付け幅の 0.5 〜0.7倍と推定される。屋根面上の剥離渦の規模が小さい が、そのエネルギーがかなり大きく、無次元ピーク周波数 近傍では速度成分wのパワースペクトルの值が接近流の值 の約10倍となっている。建物屋上に排出源がある場合に は污染物質の拡散プロセスが建物近傍の剥離性状に大きく 依存する。Fig.17にはその一例を示す。建物密度10\%で は、トレーサガスが排出源の上流および下流㑡の両方に拡 散されるが。建物密度30\%を超えると、上流側にはトレー サガスが検出されず、排出源の下流側に高漫度城が形成さ れている。この様な渡度パターンの変化は、屋根面上にお ける流れの性状の違いによるものである。建物密度が10\% の場合は、屋根面上の流れが剥離するために屋根面上の逆 流の発生頻度が13.7\%となり、そのため排出源の上流侧に もトレーサガスは輸送される。一方、建物密度が大きくな ると、屋根面上の流れの剥離がなくなり、その結果トレー サガスは排出源の下流側に流される。一般に平均瀑度の分 布は流れの平均値とその標準偏差が分かれば予測可能であ る。Fig. 18には建物中心軸上の惯度分布を示す。図中の実 線は(1)式による予測値を表し、実験結果をよく再現してい ることが分かる。

$$
C^{*}=\frac{U}{U_{\text {ROOF }}} \frac{H^{2}}{I_{c}^{2} x^{2 m}} \cdot c_{r}
$$

ここで浱度の隇衰を表す指数 $\mathrm{m}$ と比例定数 $\mathrm{c}_{\mathrm{r}}$ は実験から定 め、それぞれ0.63と0.55である。式中の乱流強度 $\mathrm{I}_{\mathrm{u}}$ と風速

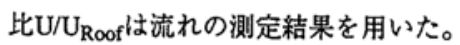

(a) $10 \%$

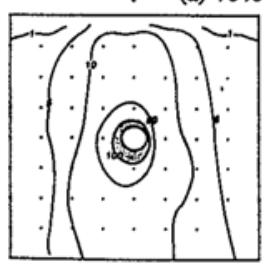

(b) $30 \%$

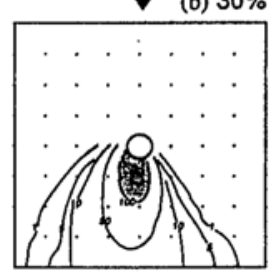

Fig.17 屋根面上の水平港度分布 (a)密度 $10 \%$; (b) $30 \%$

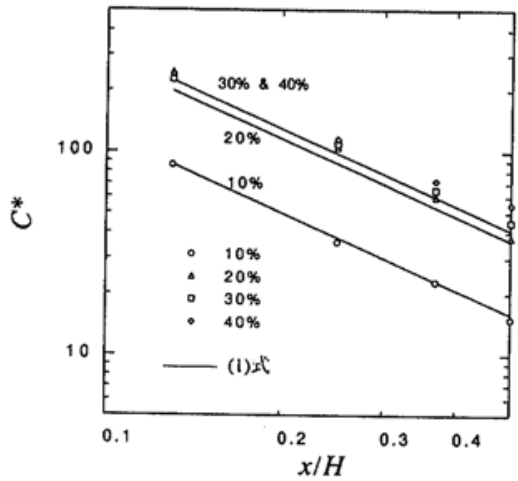

Fig.18 建物中心軸上の濃度分布

\section{3. まとめ}

本研究では大気境界層の最下層のラフネスサブレイア内 の流れ場を現地観測及び風洞実験により調べ、ラフネスサ ブレイア内の流れと拡散現象を支配する幾つかのタイプの 乱流組織運動の性質を明らかにした。Fig.19にはこれらの乱 流組織運動の概念図を示す。建物群上層には大規模組織運 動が存在し、建物群内外の物質の輸送に重要な役割を担 う。一方、建物群内にはカルマン渦やlee eddyに代表される ような乱流組織運動が存在し、建物群内の流れ场と抁散現 象をドラマチックに変化させる。更に個々の建物屋根面を 見ると、剥離渦は屋根面上の流れと拡散現象を支㥢する。 スケール的に見ると、建物群上層の乱流組織運動の長さは 建物見付け幅の約50倍であるのに対して、建物後流域のカ ルマン渦は建物見付け幅の約 5 倍程度、また建物屋根面の剥 離渦は建物見付け幅の0.5倍である。その差は2桁にもなる。

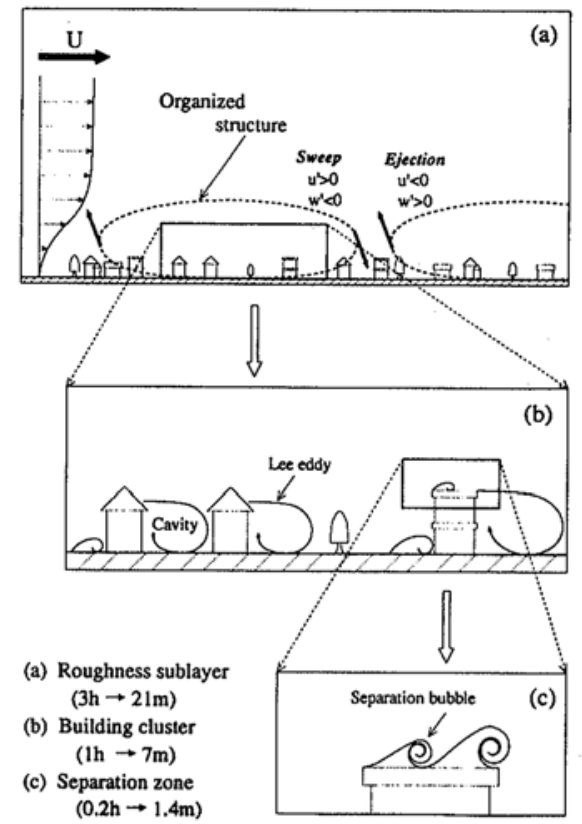

Fig.19 ラフネスサブレイア内における各種の乱流運動

参考文献 1) 孟岩、老川進: 都市キャノピー近傍における 組織的乱流運動, ながれ, Vol.14, 1995, pp.233-244. 2) S. Oikawa and Y. Meng : Turbulence characteristics and organized motion in a suburban roughness sublayer, Boundary-Layer Meteorol. , Vol. 74, 1995, pp.289-312. 3) 孟岩、老川進 : 建 物群内における流れと拡散に関する実験的研究, その 1 流 れ場の測定, 大気環境学会誌, Vol.32, No.2, 1997, pp.136147. 4) 老川進、孟岩 : 建物群内における流れと拡散に関す る実験的研究, その 2 漫度場の測定, 大気環境学会 誌,

Vol.32, No.2, 1997, pp.148-156. 5) 孟岩、日比一喜 : 高層建 物屋上の流れの乱流特性と組織的な渦運動, 日本風工学会誌 , No.72, 1997, pp.233-244. 6) S. Oikawa and Y. Meng : A field study of diffusion around a model cube in a suburban roughness sublayer, Boundary- Layer Meteorol., Vol. 84, 1997, pp.399-410. 7) 老川進、孟岩：建物後流における短時間 ピーク惯度性状について, 大気環境学会誌, 1998 (印刷中) 